sheath-like portion of the whorl, ranged in two or three concentric circles between each two whorls of leaves. Each sporangium is borne on a thin stalk, from the apex of which it is suspended, bending over towards the axis. At the bend, just where the stalk passes over into the base of the sporangium, we find a crested ridge, characterized by large thick-walled epidermal cells, like those of an annulus. Zeiller has come to the same conclusions from studying specimens preserved as impressions, which Williamson arrives at from the sections of his Bowmanites Dawsoni, and has declared the two forms to be identical, both belonging to Sphenophyllum cuneifolium. It seems, however, that this specific identification will not hold good.

The author found exactly the same structure in the original specimen of Borwmanites germanicus, Weiss, and in a fruit-spike of Sphenophyllum emarginatum in the Dresden Museum.

A different structure, however, is exhibited by a fragment of a cone, which the author has named Bowmanites Römeri, and which was found by Ferdinand Römer on the refuse-heaps of the Nieldzielisko Colliery in Cracow. In the first place, the superposition of the successive whorls forming the spike could here be determined with certainty. It could further be shown that several successive circles of sporangium-pedicels are inserted upon each whorl. While, however, in all forms of Sphenophyllum previously investigated, only a single sporangium is borne on the recurved end of the pedicel, in the new form two sporangia are suspended from a scale-like enlargement at the apex of each pedicel. In all other points of its organization there is the greatest similarity with the specimens already known.

H. GRAF ZU SOLMS-LAUBACH, Strassburg.

\title{
PRELIMINARY NOTE UPON THE STRUCTURE OF
} BACTERIAI CELLS ${ }^{1}$.- In this preliminary paper, which is a continuation of some work already referred to in the Annals of Botany ${ }^{2}$, a short account is given of observations which have been in progress for some time upon the structure of bacterial cells, especially with reference to the question of the presence or absence of a nucleus. It is, I think, generally admitted that the structure of the bacterial cell is of a simpler kind than that of other cells; but nearly all observers agree in stating that some kind of structure akin to the nucleus is

1 Abstract of a paper read at the Ipswich meeting of the British Association before the Botanical Section.

${ }^{2}$ Annals of Botany, Vol. v, p. 5 I3 3 . 
present. Bütschli has pointed out the existence of a central body in various bacterial cells, the structure of which is similar in many respects to that of the nucleus in some forms of Infusoria; but whether Bütschli's central body is to be regarded as a nucleus or not, depends upon the interpretation to be placed upon certain structures which, according to Bütschli, are to be regarded as cytoplasmic. The discussion of this question must, however, be reserved for the complete paper; I propose now merely to give an outline of my own observations without referring to the numerous other observers who have made a study of the subject.

The first form to be described is a short Bacillus, oval in outline, sometimes almost of a Coccus-form, which was found forming a pellicle upon water containing a quantity of putrefying tadpoles. In this form the cell-wall appears to possess a thick gelatinous membrane which stains, if at all, only slightly. In the protoplast two parts can be distinguished - a central rod which stains deeply in fuchsin and other aniline dyes, and fairly deeply in Delafield's haematoxylin, and is not digested by pepsin; and a slightly stainable substance in connexion with it, which is only distinctly visible at the two ends of the cell. Such a structure is perhaps the simplest to be found in any bacterial cell. Division of the cell is always preceded by division of the central rod.

In other Bacteria the structure of the cell is not quite so simple, but, as I hope to show in the complete paper, the structure of all bacterial cells may be referred to this type, and they may be regarded merely as more or less differentiated forms of this simple one. In Spirillum undula, for example, numerous deeply stained bands are to be seen in specimens carefully stained with various aniline dyes, especially fuchsin, crossing the cell in a transverse direction; these vary in number and size in different individuals. On examining them closely we find that they are peripheral and in close contact with the cell-wall, and do not extend all across the cell. They are connected with one another by a layer of less deeply stained substance. They apparently increase in number by a more or less regular process of division, and at certain stages they may divide more irregularly and even form granules arranged at the periphery of the cell and connected together by a network of the less deeply stained substance. Between the simple form first described and this much more complicated structure of Spirillum undula, forms will be described which show that we are dealing in both cases with practically the same organization. 
We may, I think, conclude that in a bacterial cell there are two different substances to be recognized - a nuclear substance and a cytoplasmic substance; that the nuclear substance has a definite structure, which is found in principle in all bacterial cells, and which plays an important part in the division of the cell; but that it is simpler in structure and form than the nucleus of the higher plants and animals.

HAROLD WAGER, Leeds.

THE WEALDEN FLORA ${ }^{1}$. - The Wealden strata of Surrey, Sussex, Kent, and the Isle of Wight have long been familiar to geologists as the delta-deposits of a large freshwater, or possibly brackish, lake of Lower Cretaceous age. Bones of Iguanodon and the remains of other fossil animals were discovered in these beds many years ago, and latterly fragments of a genus of Mammalia have been described from Wealden strata. The vegetation which grew on the land bordering the lake has hitherto been known to us in the form of a few meagre specimens of Pteridophytes and Gymnosperms preserved in the delta sediments.

During the last few years there have been discovered in the Wealden rocks of the Hastings district numerous and clearly preserved examples of this interesting flora, and, thanks to the energy and enthusiasm of Mr. Rufford, the Wealden flora is now much more fully represented in the collections of the National Museum.

In a short note ${ }^{2}$, it is impossible to do more than enumerate the species which have been determined from the material in the Rufford collection, with the addition of those first described by Stokes and Webb, Mantell, Carruthers, Gardner, and others. The following list includes such British species of Wealden plants as are at present known, but we may confidently expect that fresh material will soon be acquired from the rich plant-bearing strata of Ecclesbourne and Fairlight.

AlGaE: Algites valdensis, sp. nov.; A. catenelloides, sp. nov.; Chara Knowltoni, sp. nov. Hepaticae: Marchantites Zeilleri, sp. nov. Pteridophyta: Equisetites Lyelli, Mant.; E. Burchardti, Dunk.; E. Yokoyamae, sp. nov.; Onychiopsis Mantelli, (Brong.); O. elongata, (Geyl.); Acrostichopteris Ruffordi, sp. nov.; Matonidium Göpperti, (Ett.); Protopteris Witteana, Schenk; Ruffordia Göpperti(Dunk.); Cladophlebis

1 Read before the Botanical Section of the British Association at Ipswich.

${ }^{2}$ For a fuller account of this flora see Fossil Plants of the Wealden (British Museum Catalogue), Part I, 1894, and Part II (in the Press). 


\section{$2 \mathrm{BHL}$ Biodiversity Heritage Library}

Wager, Harold. 1895. "Preliminary note upon the structure of bacterial cells." Annals of botany 9, 659-661.

https://doi.org/10.1093/oxfordjournals.aob.a090762.

View This Item Online: https://www.biodiversitylibrary.org/item/233478

DOI: https://doi.org/10.1093/oxfordjournals.aob.a090762

Permalink: https://www.biodiversitylibrary.org/partpdf/318401

\section{Holding Institution}

Smithsonian Libraries

\section{Sponsored by}

Biodiversity Heritage Library

\section{Copyright \& Reuse}

Copyright Status: Not in copyright. The BHL knows of no copyright restrictions on this item.

This document was created from content at the Biodiversity Heritage Library, the world's largest open access digital library for biodiversity literature and archives. Visit BHL at https://www.biodiversitylibrary.org. 